\title{
In-Vitro Inhibition of Human Lipase PS by Polyphenols From Kiwi Fruit
}

\author{
Eidenberger Thomas ${ }^{1}$, Selg Manuel ${ }^{1}$, Fuerst Sigrid $^{1} \&$ Krennhuber Klaus ${ }^{1}$ \\ ${ }^{1}$ Upper Austria University of Applied Sciences, Bio- and Environmental Engineering, Stelzhamerstr. 23, 4600 \\ Wels, Austria \\ Correspondence: Eidenberger Thomas, Upper Austria University of Applied Sciences, Bio- and Environmental \\ Engineering, Stelzhamerstr. 23, 4600 Wels, Austria. E-mail: thomas.eidenberger@fh-wels.at
}

Received: June 10, 2013 Accepted: December 10, 2013 Online Published: April 16, 2014

doi:10.5539/jfr.v3n4p71 URL: http://dx.doi.org/10.5539/jfr.v3n4p71

\begin{abstract}
Polyphenols are widely distributed in higher plants. It is well recognized that they are responsible for many beneficial effects observed in humans after ingestion of vegetables and fruits. Kiwis (Actinidia chinensis) are an increasingly popular fruit in Europe and contain a wide range of polyphenols.

Different preparations from kiwi fruits were compared for the content of soluble and condensed polyphenols and tested in-vitro for inhibition of human pancreatic lipase. It is shown that human pancreatic lipase is substantially inhibited by kiwi polyphenols as long as the proportion of condensed polyphenols remains intact. Lipase inhibition is negligible when condensed polyphenols are hydrolysed by acidic treatment. It was also demonstrated that Kiwi polyphenols do not precipitate proteins as described for the tannin class of condensed polyphenols. Hence, the inhibitory effect of condensed Kiwi polyphenols is not considered to be related to unspecific enzyme inactivation by a tannin-like effect.
\end{abstract}

Keywords: human lipase PS, inhibition, polyphenols, enzyme assay, Kiwi, Actinidia chinensis

\section{Introduction}

Polyphenols (PPs) are widely distributed in plants and are a major class of secondary plant products. More than 5000 different PPs have been identified and the estimated number of PPs found in nature is expected to be much higher due to the complexity of this class of compounds. In general, PPs present in plants are categorized as soluble PPs or as condensed PPs (Beecher, 2003; Khanbabaee \& van Ree, 2001; Maatta-Riihinen, Kamal-Eldin, Mattila, Gonzalez-Paramas, \& Torronen, 2004). Soluble PPs are monomers or low molecular mass conjugates whereas condensed PPs have a more complex oligomeric structure and are commonly referred to as tannins. Tannins are occasionally associated with anti-nutritional effects by forming precipitates with dietary proteins and by inactivating gut enzymes. Overwhelmingly, however, health benefits are attributed to PPs occurring in fruit, vegetables and tea, especially to the family of dietary flavonoids (Nijveldt, van Nood, van Hoorn, Boelens, van Norren, \& van Leeuwen, 2001). The health-promoting effects of fruit and vegetables are nowadays supported by evidence gathered in epidemiological, in-vitro and in-vivo studies (Lila, Yousef, Jiang, \& Weaver, 2005; Lila, 2004; Harborne \& Williams, 2000). Green tea PPs are valued for their proven anti-oxidative, anti-mutagenic, anti-carcinogenic and hypo-cholesteremic effects as well as their potential to prevent cardiovascular diseases (Murase, Nagasawa, Suzuki, Hase, \& Tokimitsu, 2002; Yang \& Wang, 1993; Benzie \& Szeto, 1999). The occurrence of catechins, gallo- and ellagitannins, which are the principal PPs sources in tea, was also demonstrated in fruits, wine and chocolate. The presence of these substances was linked to the inhibition of the angiotensin converting enzyme, the low cardiovascular mortality in countries with high red wine consumption ("French wine paradox") and anti-platelet activities (Arts, van De Putte, \& Hollman, 2000a; Arts, van De Putte, \& Hollman, 2000b; Actis-Goretta, Ottaviani, \& Fraga, 2006). In particular, the proportion of galloyl-units in PPs was shown to be correlated with apoptosis induced in prostate and breast cancer cells and the inhibition of the fatty acid synthase (Brusselmans, Vrolix, Verhoeven, \& Swinnen, 2005).

Kiwi fruits (Actinidia chinensis L.) are popular in Europe. The basic, organic composition of Kiwi fruits has been investigated (Castaldo, Lo Voi, Trifiro, \& Gherardi, 1992). Apart from the general nutritional benefits claimed for fruits, bioactive polysaccharides and glycoproteins have been characterized in Kiwi (Deters, Schroeder, \& Hensel, 2005; Balestrieri, Castaldo, Giovane, Quagliuolo, \& Servillo, 1990). Additionally, Kiwi fruits contain a 
wide range of soluble and condensed PPs (Dawes \& Keene, 1999). More than $50 \%$ of the PPs occurring in Kiwi fruit are reportedly present as condensed PPs (Imeh \& Khokhar, 2002). Recently, condensed PPs from Oolong tea were shown to substantially inhibit human pancreatic lipase (LPS) in-vitro (Nakai, et al., 2005). Also, grape seed extract rich in condensed PPs was shown to inhibit LPS (Moreno, Ilic, Poulev, Brasaemle, Fried, \& Raskin, 2003). On the other hand, previously performed studies demonstrated that soluble PPs are only weak inhibitors of LPS (Karamac \& Amarowicz, 1996). LPS is the key enzyme for digestion and absorption of triglycerides (Embleton \& Pouton, 1997). The inhibition of LPS and, thereby, the prevention of lipolysis and absorption of fatty acids is considered a successful approach in the treatment of obesity. Orlistat, a synthetic drug compound, which acts as an LPS inhibitor, was introduced successfully as an anti-obesity drug in the EU and the United States (Carriere, Renou, \& Ransac, 2001).

This study at hand tested the hypothesis that condensed PPs may inhibit LPS activity in-vitro without an anti-nutrional effect due to tannin-like enzyme inactivation.

\section{Material and Methods}

\subsection{Chemicals}

Reference standards and organic solvents (ACS or HPLC grade) were obtained from Sigma Aldrich (Vienna, Austria). Standard laboratory chemicals were p.a grade. The lipase test kit was obtained from Trinity Biotech (Jamestown, NY, USA, Cat No.: 805).

\subsection{Kiwi Sample Preparation}

Fresh kiwis (commonly consumed cultivars from New Zealand) were cleaned, mashed thoroughly and freeze dried. The lyophylisate was powdered and used for extraction of PPs. On average $1 \mathrm{~kg}$ of kiwi fruit yielded 120 $\mathrm{g}$ of dried Kiwi powder.

Kiwi extract was prepared from fresh kiwis. First, kiwis were pressed to yield juice. The press residue was extracted twice with $80 \%$ ethanol (residue/ethanol ratio $\sim 1 / 5$ ). The ethanolic extracts were combined with the juice and evaporated to dryness under reduced pressure at $42{ }^{\circ} \mathrm{C}$. On average $1 \mathrm{~kg}$ of kiwi fruit yielded $50 \mathrm{~g}$ of kiwi extract.

$1 \mathrm{~g}$ of kiwi powder or $1 \mathrm{~g}$ of kiwi extract were suspended in $100 \mathrm{ml}$ acetone/water $(3 / 2 \mathrm{v} / \mathrm{v})$ and stirred for 24 hours at room temperature, protected from light under nitrogen for extraction and enrichment of PPs. Following centrifugation (5000 rpm for $10 \mathrm{~min}$.), the clear supernatant was evaporated to dryness under reduced pressure at $42^{\circ} \mathrm{C}$. The dry mass of both samples was determined.

$1 \mathrm{~g}$ of each PPs-enriched sample was dissolved in $100 \mathrm{ml} \mathrm{CH} \mathrm{C}_{3} \mathrm{OH} / \mathrm{H}_{2} \mathrm{O}(1 / 1 \mathrm{v} / \mathrm{v})$, kept at $90{ }^{\circ} \mathrm{C}$ for 2 hours in a plastic screw-cap tube and intermittently shaken. An aliquot of the cleared supernatant was used for the quantitative determination of soluble PPs. The remaining supernatant was evaporated to dryness under reduced pressure at $50{ }^{\circ} \mathrm{C}$ and used for LPS activity assay (dilutions were prepared with $\mathrm{CH}_{3} \mathrm{OH} / \mathrm{H}_{2} \mathrm{O}(1 / 1 \mathrm{v} / \mathrm{v}$ ), sample amounts given are calculated on a dry mass basis).

$1 \mathrm{~g}$ of each PPs-enriched sample was dissolved in $100 \mathrm{ml} \mathrm{CH} \mathrm{CH}_{3} \mathrm{OH} / 1.2 \mathrm{M} \mathrm{HCl}(1 / 1 \mathrm{v} / \mathrm{v})$ and kept at $90{ }^{\circ} \mathrm{C}$ for 2 hours in a plastic screw-cap tube with intermittent shaking to completely hydrolyze the condensed PPs. An aliquot of the cleared, $\mathrm{pH}$-adjusted $(\mathrm{pH}=7, \mathrm{NaOH})$ supernatant was used for the quantitative determination of the total PPs. The remaining supernatant was evaporated to dryness under reduced pressure at $50{ }^{\circ} \mathrm{C}$ and used for LPS activity assay (dilutions were prepared with $\mathrm{CH}_{3} \mathrm{OH} / \mathrm{H}_{2} \mathrm{O}(1 / 1 \mathrm{v} / \mathrm{v})$, sample amounts given are calculated on a dry mass basis).

\subsection{Determination of Soluble and the Total PPs}

Soluble and the total PPs were determined in 3 replicate samples spectrophotometrically by the Folin-Ciocalteu assay at $720 \mathrm{~nm}$ (Singleton, Orthofer, \& Lamuela-Raventos, 1999; Vinson, Yong, Xuehui, \& Ligia, 2001). The difference between soluble PPs obtained from samples heated in $\mathrm{CH}_{3} \mathrm{OH} / \mathrm{H}_{2} \mathrm{O}$ (see above) and the total PPs obtained from samples hydrolyzed in $\mathrm{CH}_{3} \mathrm{OH} / 1.2 \mathrm{M} \mathrm{HCl}$ was attributed to the proportion/amount of condensed PPs.

Gallic acid was used for external standardisation. Results are expressed as Gallic Acid Equivalents (mmol GA-E/kg dry matter) and given as mean values \pm standard deviation (sd). Control experiments with catechin, epicatechin, tannic acid and coumaric acid confirmed the validity of the conversion to GA-E (recoveries of $\geq$ $85 \%$ for all control standards, data not shown). 


\subsection{LPS Activity Assay}

LPS activity was determined using a commercially available test kit. In short, aliquots of human LPS standard (327 IU/l), solvent or kiwi samples at different concentrations were added to $500 \mu \mathrm{L}$ of reconstituted substrate solution, mixed gently and incubated for 5 minutes at $37^{\circ} \mathrm{C}$. After addition of an activator reagent, the change in absorption rate was followed at $550 \mathrm{~nm}$ for 10 minutes. The rate of inhibition is given as the \%-decrease of LPS activity obtained in the presence of kiwi samples compared with control samples.

A dose response curve was constructed from the log/linear correlation of enzyme velocity (expressed as mmol substrate consumption/minute) and the concentration of the sample expressed as $\mu \mathrm{M}$ GA-E. Calculations are based on $7.11 \mathrm{mIU}$ LPS activity and $550 \mathrm{nmol}$ substrate per $\mathrm{ml}$ test assay solution. All samples were tested in 3 replicates and the results are given as a mean value \pm sd.

\subsection{Determination of Protein-Precipitating Tannins}

The content of tannins which are able to precipitate proteins was determined spectrophotometrically (Hagerman, \& Butler, 1978). In short, a bovine serum albumin solution was incubated with kiwi samples at different concentrations. Thereafter, the protein-tannin precipitate formed was collected, washed and the tannin content in the precipitate was quantified photometrically when reacting with $\mathrm{FeCl}_{3}$. Results were obtained by external standardization with catechin (catechin-equivalents). All samples were tested in 3 replicates and the results are given as a mean value \pm sd.

\section{Results and Discussion}

The dry mass obtained from PPs-enriched powdered Kiwi lyophylisate and Kiwi extract was $25 \%$ and $48 \%$, respectively. The content of soluble, the total and the calculated proportion of condensed PPs in these samples is shown in Table 1. The proportion of soluble PPs in PPs-enriched powdered Kiwi lyophylisate and Kiwi extract is $36.2 \%$ and $7.9 \%$ respectively of the total PPs. The corresponding values for the fraction of condensed PPs are $63.8 \%$ and $92.1 \%$, respectively. The two different extraction procedures yielded samples with a similar amount of soluble PPs but a substantially different amount of condensed PPs. Based on dry mass, Kiwi extract contains 5 times more condensed PPs when compared to powdered kiwi lyophylisate. The content and distribution of PPs observed in the powdered kiwi lyophylisate was within the range of published results whereas kiwi extract is substantially enriched in condensed PPs (Imeh \& Khokhar, 2002). This finding is especially important for this study as soluble PPs were shown to be weak inhibitors of LPS with IC50-values of $>20 \mu \mathrm{M}$ for catechin, epicatechin and gallic acid (Nakai et al., 2005). In another study phenolic acids were shown to inhibit LPS activity by no more than $30 \%$ in concentrations of up to $10 \mu \mathrm{M}$ (Karamac \& Amarowicz, 1996). Condensed PPs, on the other hand, were shown to be potent inhibitors of LPS with IC50 values down to $0.05 \mu \mathrm{M}$ for oolonghomobisflavins as pure compounds (Nakai et al., 2005).

Table 1. Soluble, condensed and total polyphenols ( $\mu$ mol GA-E/g dry mass)

\begin{tabular}{llll}
\hline \multirow{2}{*}{ Sample } & \multicolumn{3}{l}{$\mu$ mol GA-E/g dry mass (mean \pm sd, $\mathrm{n}=3$ ) } \\
& Soluble & Condensed & Total \\
\hline Polyphenol enriched Kiwi powder & $76 \pm 5$ & $134 \pm 11$ & $210 \pm 13$ \\
Polyphenol enrichted Actannine ${ }^{\circledR}$ Kiwi Extract & $56 \pm 4$ & $653 \pm 24$ & $709 \pm 27$ \\
\hline
\end{tabular}

*Gallic Acid-Equivalents.

The results of the remaining LPS activity in the presence of PPs-enriched powdered kiwi lyophylisate or Kiwi extract in different concentrations (0-40 mg sample dry mass $/ \mathrm{ml})$ are shown in Figure 1. 


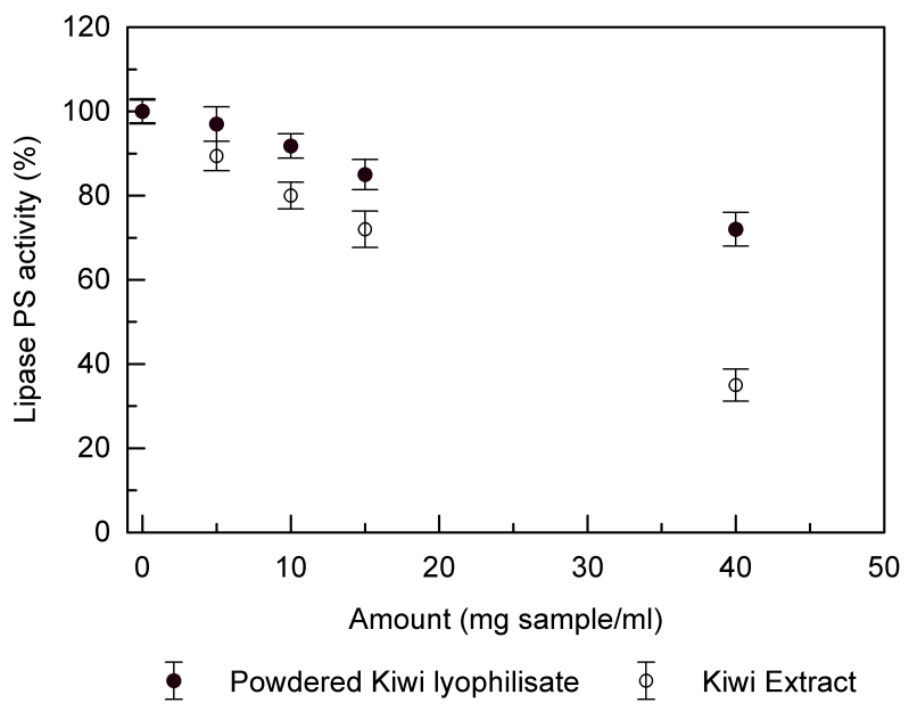

Figure 1. LPS activity in presence of PPs enriched powdered Kiwi lyophyisate (•) or Kiwi extract (o), Mean values $\pm \mathrm{sd}, \mathrm{n}=3$

In Figure 2, the activity of LPS in the presence of PPs-enriched powdered kiwi lyophylisate or kiwi extract is correlated to the amount of condensed PPs (given as $\mu \mathrm{M}$ GA-E $/ \mathrm{ml}$ ) determined in the samples. The LPS activity (\%) observed in the presence of $40 \mathrm{mg} / \mathrm{ml}$ of PPs-enriched powdered kiwi lyophylisate or kiwi extract after acidic hydrolysis is shown in Table 2. Based on dry mass kiwi extract was found to inhibit LPS considerably, more than powdered kiwi lyophylisate. When calculating the inhibition of LPS against the amount of condensed PPs present in both samples, an almost linear correlation - irrespective of the sample type- was obtained. This finding indicates that the LPS-inhibitory potential of kiwi PPs resides in the proportion of condensed PPs. Moreover it seems very likely that kiwi extract contains the same composition of condensed PPs but in a higher concentration than the powdered kiwi lyophylisate in so far as the extraction technique used for kiwi extract does not change the natural structure of the condensed kiwi PPs. These findings demonstrated that the inhibition of LPS is almost completely absent after hydrolysis of condensed PPs with methanolic $\mathrm{HCl}$, undermining the published findings that soluble PPs are only weak inhibitors of the LPS.

Table 2. LPS activity in presence of Kiwi samples with/without acidic hydrolysis of polyphenols

\begin{tabular}{lll}
\hline \multirow{2}{*}{ Sample } & \multicolumn{2}{l}{ LPS Activity \% (mean $\pm \mathrm{sd}, \mathrm{n}=3)$} \\
& Non-Hydolyzed & Hyrolyzed \\
\hline Polyphenol enriched Kiwi powder & $72 \pm 4$ & $93 \pm 7$ \\
Polyphenol enrichted Actannine ${ }^{\circledR}$ Kiwi Extract & $35 \pm 3$ & $95 \pm 8$ \\
\hline
\end{tabular}




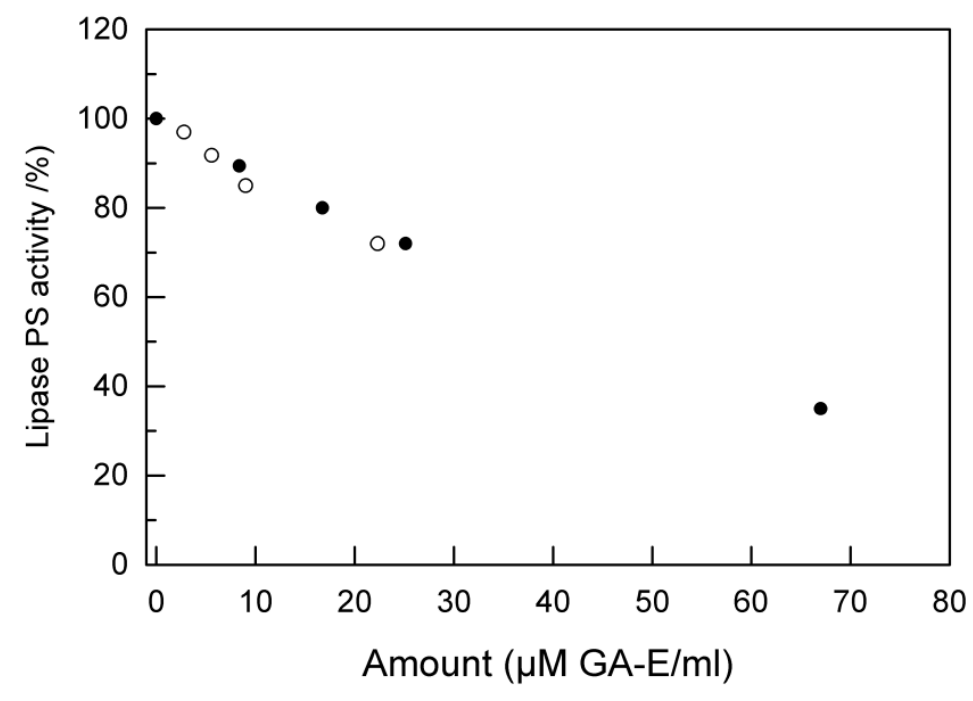

- Powdered Kiwi lyophilisate $\bigcirc \quad$ Kiwi extract

Figure 2. Correlation of LPS activity with GA-E from the fraction of condensed polyphenols in powdered Kiwi lyophyisate $(\bullet)$ or Kiwi extract (o), Mean values $\pm \mathrm{sd}, \mathrm{n}=3$

The kiwi extract sample, containing much higher amounts of condensed PPs than the powdered Kiwi lyophylisate, was tested for the potential to precipitate proteins (tannin-like effect). Up to a concentration of 100 $\mathrm{mg} / \mathrm{ml}$ the amount of tannins which precipitate protein was lower than $10 \mu \mathrm{g}$ catechin-equivalents $/ \mathrm{ml}$. As $100 \mathrm{mg}$ of kiwi extract $/ \mathrm{ml}$ represents a concentration that inhibits LPS by more than $70 \%$ it is concluded that the biological effect of condensed PPs is not related to an unspecific tannin-like inactivation of LPS.

A dose response curve constructed for the LPS substrate consumption/minute against $\mu \mathrm{M}$ GA-E of condensed PPs indicates an $\mathrm{IC}_{50}$-value in the range of about 1-5 $\mu \mathrm{M}$ GA-E (Figure 3). This range suggests a substantial potential for condensed kiwi PPs to inhibit LPS, especially when considering that the condensed PPs tested were present in crude extract preparations. Further purification and fractionation of the condensed PPs may yield an even stronger effect.

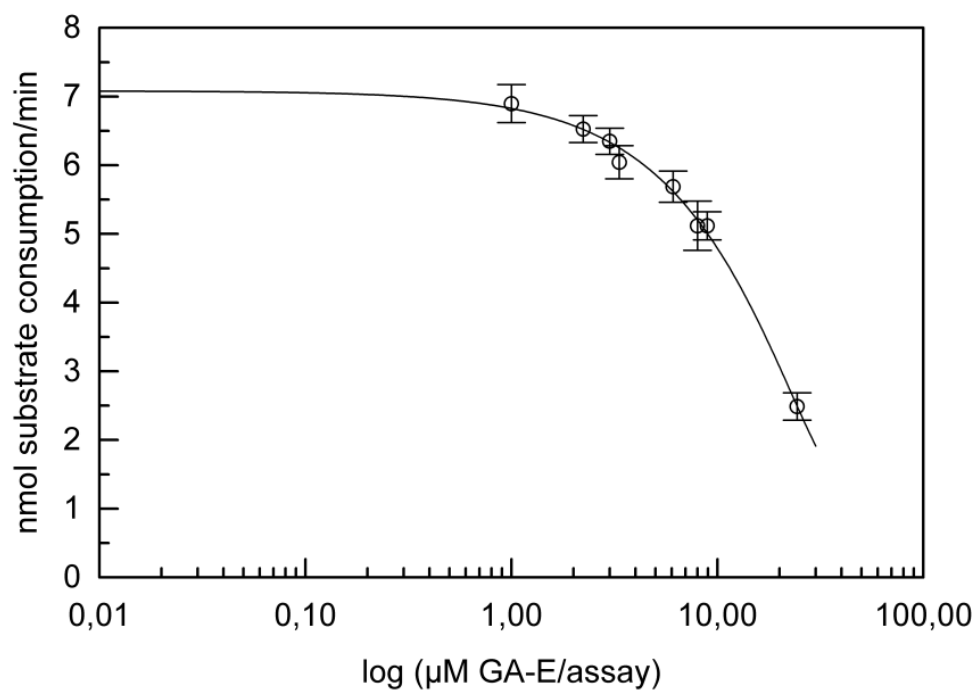

Figure 3. Dose-Response Curve for condensed Kiwi polyphenols (as GA-E) and LPS activity,

Mean values $\pm \mathrm{sd}, \mathrm{n}=3$ 
In summary, this study provides convincing evidence that condensed PPs from kiwi fruit are likely to cause LPS inhibition without producing anti-nutrional effects as described for certain tannins. Further studies are planned to elucidate the chemical structure of these PPs.

\section{Acknowledgements}

Commercial samples of kiwi extract $\left(\right.$ Actannine $\left.^{\circledR}\right)$ were kindly provided by Omnica Ltd., Japan.

\section{References}

Actis-Goretta, L., Ottaviani, J. I., \& Fraga, C. G. (2006). Inhibition of angiotensin converting enzyme activity by flavanol-rich foods. J Agric Food Chem, 54, 229-234. http://dx.doi.org/10.1021/jf052263o

Arts, I. C., van De Putte, B., \& Hollman, P. C. (2000a). Catechin Contents of Foods Commonly Consumed in The Netherlands. 1. Fruits, Vegetables, Staple Foods, and Processed Foods. J Agric Food Chem, 48(5), 1746-1751. http://dx.doi.org/10.1021/jf000025h

Arts, I. C., van De Putte, B., \& Hollman, P. C. (2000b). Catechin contents of foods commonly consumed in The Netherlands. 2. Tea, wine, fruit juices, and chocolate milk. J Agric Food Chem, 48(5), 1752-1757. http://dx.doi.org/10.1021/jf000026+

Balestrieri, C., Castaldo, D., Giovane, A., Quagliuolo, L, \& Servillo, L. (1990). A glycoprotein inhibitor of pectin methylesterase in kiwi fruit (Actinidia chinensis). Eur $J$ Biochem. 193, 183-187. http://dx.doi.org/10.1111/j.1432-1033.1990.tb19321.x

Beecher, G. R. (2003). Overview of Dietary Flavonoids: Nomenclature, Occurrence and Intake. J. Nutr., 133, 3248S-3254S.

Brusselmans, K., Vrolix, R., Verhoeven, G., \& Swinnen, J. V. (2005) Induction of Cancer Cell Apoptosis by Flavonoids Is Associated with Their Ability to Inhibit Fatty Acid Synthase Activity. JBC, 280, 5636-5645. http://dx.doi.org/10.1074/jbc.M408177200

Benzie, I. F. F., \& Szeto, Y. T. (1999). Total antioxidant capacity of teas by the ferric reducing/antioxidant power assay. J. Agric. Food Chem., 47, 633-636. http://dx.doi.org/10.1021/jf9807768

Carriere, F., Renou, C., \& Ransac, S. (2001). Inhibition of gastrointestinal lipolysis by Orlistat during digestion of test meals in healthy volunteers. Am J Physiol Gastrointest Liver Physiol. 281, G16-28.

Castaldo, D., Lo Voi, A., Trifiro, A., \& Gherardi, S. (1992). Composition of Italian Kiwi (Actinidia chinensis) Puree. J Agric Food Chem., 40, 594-598. http://dx.doi.org/10.1021/jf00016a013

Dawes, H. M., \& Keene, J. B. (1999). Phenolic Composition of Kiwifruit Juice. J. Agric. Food Chem., 47, 2398-2403. http://dx.doi.org/10.1021/jf9810261

Deters, A. M., Schroeder, K. R., \& Hensel, A. (2005). Kiwi Fruit (Actinidia chinensis L.) Polysaccharides Exert Stimulating Effects on Cell Proliferation via Enhanced Growth Factor Receptors, Energy Production, and Collagen Synthesis of Human Keratinocytes, Fibroblasts, and Skin Equivalents. J Cell Physiol, 202, 717-722. http://dx.doi.org/10.1002/jcp.20161

Embleton, J. K., \& Pouton, C. W. (1997). Structure and Function of gastrointestinal lipases. Adv Drug Deliv Rev, 25, 15-21. http://dx.doi.org/10.1016/S0169-409X(96)00488-7

Hagerman, A. E., \& Butler, L. G. (1978). Protein precipitation method for the quantitative determination of tannins. J. Agric. Food Chem., 26, 809-812. http://dx.doi.org/10.1021/jf60218a027

Harborne, J. B., \& Williams, C. A. (2000). Advances in flavonoid research since 1992. Phytochemistry., 55, 481-504. http://dx.doi.org/10.1016/S0031-9422(00)00235-1

Imeh, U., \& Khokhar, S. (2002). Distribution of Conjugated and Free Phenols in Fruits: Antioxidant Activity and Cultivar Variations. J Agric Food Chem., 50, 6301-6306. http://dx.doi.org/10.1021/jf020342j

Karamac, M., \& Amarowicz, R. (1996). Inhibition of pancreatic Lipase by phenolic acids - Examination in vitro. Z. Naturfosch., 51c, 903-905.

Khanbabaee, K., \& van Ree, T. (2001). Tannins: Classification and Definition. Nat. Prod. Rep., 18, 641-649. http://dx.doi.org/10.1039/b1010611

Lila, M. A. (2004). Anthocyanins and Human Health: An In Vitro Investigative Approach. J Biomed Biotechnol., 5, 306-313. http://dx.doi.org/10.1155/S111072430440401X

Lila, M. A., Yousef, G. G., Jiang, Y., \& Weaver, C. M. (2005). Sorting out bioactivity in flavonoid mixtures. $J$ 
Nutr., 135, 1231-1235.

Maatta-Riihinen, K. R., Kamal-Eldin, A., Mattila, P. H., Gonzalez-Paramas, A. M., \& Torronen, A. R. (2004). Distribution and contents of phenolic compounds in eighteen Scandinavian berry species. $J$ Agric Food Chem., 52(14), 4477-4486. http://dx.doi.org/10.1021/jf049595y

Moreno, D. A., Ilic, N., Poulev, A., Brasaemle, D. L., Fried, S. K., \& Raskin, I. (2003). Inhibitory effects of grape seed extract on lipases. Nutrition, 19, 876-879. http://dx.doi.org/10.1016/S0899-9007(03)00167-9

Murase, T., Nagasawa, A., Suzuki, J., Hase, T., \& Tokimitsu, I. (2002). Beneficial effects of tea catechins on diet-induced obesity: Stimulation of lipid catabolism in the liver. Int. J. Obesity, 26, 1459-1464. http://dx.doi.org/10.1038/sj.ijo.0802141

Nakai, M., Fukui, Y., Asami, S., Tovoda-Ono, Y., Iwashita, T., ... Kiso, Y. (2005). Inhibitory Effects of Oolong Tea Polyphenols on Pancreatic Lipase in Vitro. J. Agric. Food Chem., 53, 4593-4598. http://dx.doi.org/10.1021/jf047814+

Nijveldt, R. J., van Nood, E., van Hoorn, D. E., Boelens, P. G., van Norren, K., \& van Leeuwen, P. A. (2001). Flavonoids: a review of probable mechanisms of action and potential applications. Am J Clin Nutr., 74(4), 418-425.

Singleton, V. L., Orthofer, R., \& Lamuela-Raventos, R. M. (1999). Analysis of total phenols and other oxidative substrates by means of Folin-Ciocalteau reagent. Packer, L. Methods Enzymol., 299, 152-178. http://dx.doi.org/10.1016/S0076-6879(99)99017-1

Vinson, J. A., Yong, H., Xuehui, S., \& Ligia, Z. (2001). Phenol antioxidant quantity and quality in food: fruits. $J$ Agric Food Chem., 49, 5315-5321. http://dx.doi.org/10.1021/jf0009293

Yang, C. S., \& Wang, Z. Y. (1993). Tea and cancer. J. Natl. Cancer Inst., 85, 1038-1049. http://dx.doi.org/10.1093/jnci/85.13.1038

\section{Copyrights}

Copyright for this article is retained by the author(s), with first publication rights granted to the journal.

This is an open-access article distributed under the terms and conditions of the Creative Commons Attribution license (http://creativecommons.org/licenses/by/3.0/). 